\title{
Exosome Light in Regenerative Dentistry
}

\author{
Aylin Islam ${ }^{1 *}$ and Serap Çetiner ${ }^{2}$ \\ ${ }^{1}$ Paediatric Dentistry Department, Near East University, Cyprus \\ ${ }^{2}$ Paediatric Dentistry Department, Kyrenia University, Cyprus
}

Submission: November 06, 2017; Published: January 19, 2018

*Corresponding author: Aylin Islam, Department of Pediatrics Dentistry, Near East University, Cyprus, Tel: +90(392)6802030; Fax: +90-3926802025; Email: serap.cetiner@neu.edu.tr

\begin{abstract}
Among children and adults, the prevalence of dental caries is one of the most common health problems that is experienced by approximately $90 \%$ of the global population and is characterized by infected and necrotic pulp. The current clinical treatment of choice in the case of latter stage - necrotic dental pulp (DP) infections is traditional root canal therapy. Besides this traditional technique, 'revascularization' biological procedure used as the current regenerative protocol to control the root canal infection and regenerate a pulp tissue through the endodontic space for immature necrotic permanent teeth. In this review, the pulp vitality maintenance, stem cell-free therapies and the benefits of stem cell-derived exosomes advantages for regenerative dentistry and regenerative medicine fields are tried to summarize.
\end{abstract}

Keywords: Exosomes; Regenerative dentistry; Dental pulp

Abbreviations: DP: Dental Pulp; RCT: Root Canal Therapy; DPSCS: Dental Pulp Stem Cells; MSCS: Mesenchymal Stem Cells; MVBS: Multi-Vesicular Bodies

\section{Introduction}

Among children and adults, the prevalence of dental caries is one of the most common health problems that is experienced by approximately $90 \%$ of the global population and is characterized by infected and necrotic pulp. Poor oral hygiene is accepted as the primary etiologic agent of dental caries. When these dental caries expand, they can cause irreversible degeneration in the mineralized and soft tissues of the teeth. In advanced stages, the situation deteriorates, reaches the Dental Pulp (DP) and subsequently causes bacterial infected DP that leads to necrosis of the vital pulp tissue. In such cases, the treatment option is usually a pulpectomy [1-3].

The current clinical treatment of choice in the case of latter stage - necrotic DP infections is traditional Root Canal Therapy (RCT). Unfortunately, in this therapy the living tissue is removed and replaced with a foreign filling material. Consequently, the tooth loses its vitality, sensitivity, becomes exposed to secondary infections, post-operative pain and periapical lesions originating from coronal micro leakage may occur after endodontic therapy [4,5-8]. The current regenerative protocol used to control the root canal infection and regenerate a pulp tissue through the endodontic space for immature necrotic permanent teeth is the 'revascularization' biological procedure $[3,9,10]$.

Although the DP revascularization procedure has been adapted to clinics and is recommended as an effective treatment option for immature necrotic teeth by the American Association of Endodontics, difficulties still remain in terms of pure pulpal regeneration due to the impossibility of a naturally well-organized odontoblastic layer through the dentinal walls [11-13]. In this review, the pulp vitality maintenance, stem cell-free therapies and the benefits of stem cell-derived exosomes advantages for regenerative dentistry and regenerative medicine fields are tried to summarize.

\section{Discussion}

When the multiple stem cell profile of DP tissue (from the pulpal tissues of exfoliated primary teeth, permanent teeth, wisdom teeth and supernumerary teeth) has been identified, the stem cell sources of Dental Pulp-Dental Pulp Stem Cells (DPSCS) have been started to use as a potential stem cell-based therapy tool for regeneration of the dentin-pulp complex in regenerative dentistry [14-17]. However, the slow proliferation and differentiation of DPSCS in vivo and the severe decline of stem/ progenitor cell numbers in the DP with the ageing process create challenges related to stem cell-based therapies $[16,18]$.

\section{New Hope: 'Stem Cell Derived Exosomes'}

Exosomes are extracellular nanosized membrane vesicles produced during the invagination process of the endosomal membrane of specialized intracellular Multi-Vesicular Bodies 
(MVBS) [19-21]. The mesenchymal origin of DPSCS, the therapeutic application of exosomes, particularly Mesenchymal Stem Cells (MSCS)-derived exosomes, has extra significance for the field of regenerative dentistry. MSCS derived exosomes have been reported to play an important role in wound healing (angiogenesis in vitro for vascular regeneration), the specific lineage differentiation of MSCS, anti-inflammatory features against acute inflammation, biomimetic tools for dental pulp-like regeneration and odontogenic differentiation applications, bone regeneration by osteoinductivity and osteogenesis activity $[3,22$ 26].

\section{Conclusion}

It is obvious that exosome-based therapies can be a good alternative choice against to the disadvantages stem cell-based therapies.

As a result, the future of regenerative dentistry field could be formed around dental derived exosome therapies with exosomes' anti-inflammatory, immunomodulatory and osteo/odonto inductive roles, particularly for desired pure dentin-pulp complex regeneration.

\section{Conflict of Interest}

The authors report no conflicts of interest. The authors alone are responsible for the content and writing of this paper.

\section{References}

1. Ravindran S, Huang CC, George A (2014) Extracellular matrix of dental pulp stem cells: applications in pulp tissue engineering using somatic MSC $_{\mathrm{s}}$. Front Physiol 4(395).

2. Nakashima M, Iohara K, Murakami M, Nakamura H, Sato Y, et al. (2017) Pulp regeneration by transplantation of dental pulp stem cells in pulpitis: a pilot clinical study. Stem Cell Res Ther 8(1): 1-13.

3. Huang CC, Narayanan R, Alapati S, Ravindran S (2016) Exosomes as biomimetic tools for stem cell differentiation: Applications in dental pulp tissue regeneration. Biomaterials 111: 103-115.

4. Ducret M, Fabre H, Celle A, Mallein-Gerin F, Perrier-Groult E, et al. (2017) Current challenges in human tooth revitalization. Biomed Mater Eng 28(s1): S159-168.

5. Cvek M (1992) Prognosis of luxated non-vital maxillary incisors treated with calcium hydroxide and filled with gutta-percha. A retrospective clinical study. Endod Dent Traumatol 8(2): 45-55.

6. Cordeiro MM, Dong Z, Kaneko T, Zhang Z, Miyazawa M, et al. (2008) Dental pulp tissue engineering with stem cells from exfoliated deciduous teeth. J Endod 34(8): 962-969.

7. Nixford DR, Moana-Filho EJ, Law AS, McGuire LA, Hodges JS, et al. (2010) Frequency of nonodontogenic pain after endodontic therapy: a systematic review and meta-analysis. J Endod 36(9): 1494-1498.

8. Gale MS (2000) Coronal Microleakage. Ann R Australas Coll Dent Surg 15: 299-305.
9. Hargreaves KM, Diogenes A, Teixeira FB (2013) Treatment options: biological basis of regenerative endodontic procedures. J Endod 39(s3): S30-S43.

10. Law AS (2013) Considerations for regeneration procedures. J Endod 39(s3): S44-56.

11. American Association of Endodontists (AAE) (2016) Clinical Considerations for a Regenerative Procedure.

12. Schmalz G, Smith AJ (2014) Pulp development, repair, and regeneration: challenges of the transition from traditional dentistry to biologically based therapies. J Endod 40(s4): S2-S5.

13. Diogenes A, Ruparel NB, Shiloah Y, Hargreaves KM (2016) Regenerative endodontics: A way forward. J Am Dent Assoc 147(5): 372-380.

14. Collart-Dutilleul PY, Chaubron F, Vos JD, Cuisiner FJ (2015) Allogenic banking of dental pulp stem cells for innovative therapeutics. World J Stem Cells 7(7): 1010-1021.

15. Naddeo P, Laino L, La Noce M, Piattelli A, De Rosa A, et al. (2015) Surface biocompatibility of differently textured titanium implants with mesenchymal stem cells. Dent Mater 31(3): 235-243.

16. Meguid EA, Ke Y, Ji J, El-Hashash AHK (2017) Stem Cell Applications In Bone and Tooth Repair And Regeneraion: New Insights, Tools and Hopes. J Cell Physiol 233(3): 1825-1835.

17. Nakashima M, Iohara K (2014) Mobilized dental pulp stem cells for pulp regeneration: initiation of clinical trial. J Endod 40(s4): S26-S32.

18. Smith AJ, Patel M, Graham L, et al. (2015) Molecular Signaling. Oral Biosciences and Medicine 2: 127-132.

19. Batrakova EV, Kim MS (2015) Using exosomes, naturally-equipped nanocarriers, for drug delivery. J Control Release 219: 396-405.

20. Raposo G, Stoorvogel W (2013) Extracellular vesicles: exosomes, microvesicles, and friends. J Cell Biol 200(4): 373-383.

21. Yáñez-Mó M, Siljander PR, Andreu Z, Zavec AB, Borràs FE, et al. (2015) Biological properties of extracellular vesicles and their physiological function. J Extracell Vesicles 4: 27066.

22. Narayanan R, Huang CC, Ravindran S (2016) Hijacking the Cellular Mail: Exosome Mediated Differentiation of Mesenchymal Stem Cells. Stem Cells Int 2016: 3808674.

23. Shabbir A, Cox A, Rodriguez-Menocal L, Salgado M, Badiavas EV (2015) Mesenchymal Stem Cell Exosomes Induce Proliferation and Migration of Normal and Chronic Wound Fibroblasts, and Enhance Angiogenesis In Vitro. Stem Cells Dev 24(14): 1635-1647.

24. Alcayaga-Miranda F, Varas-Godoy M, Khoury M (2016) Harnessing the Angiogenic Potential of Stem Cell-Derived Exosomes for Vascular Regeneration. Stem Cells Int 2016: 3409169.

25. Pivoraite U, Jarmalaviciute A, Tunaitis V, Ramanauskaite G, Vaitkuviene A, et al. (2015) Exosomes from Human Dental Pulp Stem Cells Suppress Carrageenan-Induced Acute Inflammation in Mice. Inflammation 38(5): 1933-1941.

26. Zhang J, Liu X, Li H, Chen C, Hu B, et al. (2016) Exosomes/tricalcium phosphate combination scaffolds can enhance bone regeneration by activating the PI3K/Akt signaling pathway. Stem Cell Res Ther 7(1): 136. 
Your next submission with Juniper Publishers will reach you the below assets

- Quality Editorial service

- Swift Peer Review

- Reprints availability

- E-prints Service

- Manuscript Podcast for convenient understanding

- Global attainment for your research

- Manuscript accessibility in different formats

( Pdf, E-pub, Full Text, Audio)

- Unceasing customer service

Track the below URL for one-step submission https://juniperpublishers.com/online-submission.php 